INTERNATIONAL JOURN AL OF RESEARCHES IN BIOSCIENCES, AGRICULTURE AND TECHNOLOGY (c) VISHWASHANTI MULTIPURPOSE SOCIETY (Global Peace Multipurpose Socie ty) R. No. MH-659/13 (N) www.vmsindia.org

\title{
PRODUCTION OF SHRIKHAND FROM SOYMILK AND CHEMICAL ANALYSIS OF THEIR PRODUCT
}

\author{
G. P. Kadam 1 , S. R. Narawade ${ }^{2}$, M. P. Mahale Ma $^{2}$ \\ 1 De pt. of Biotechnology, Deogiri College Aurangabad. \\ ${ }^{2}$ Dept. of Biotechnology, Govt. Institute of Science Aurangabad. \\ drushtikharat@gmail.com
}

\begin{abstract}
Soymilk is most popular non-dairy milk alternative made from nutritionally dense Soybean. Soyshrikhand is an inexpensive remarkable versatile high protein food from soybean. Soyshrikhand contains higher amount of protein and low amount of fat as comparative buffalo milk shrikhand. In presence study was carry out in an attempt to preparation of soymilk and formation of their product using the process such as coagulation, desiccation \& fermentation. Comparative clarify the lipid contain were determine in soyshrikhand and market buffalo milk shirkhand by acid value test result shows the soyshrikhand shows concentration of fat i.e.7.3 $\mathrm{mg} / \mathrm{ml} \mathrm{\&} \mathrm{buffalo}$ milk shrikhand i.e. $12 \mathrm{mg} / \mathrm{ml}$ shows. It was concluded that in soyshrikhand low concentration of fat is present it significant to health conscious person and use for those person who have fat problem, diabetes patients, heart disease $\&$ certain cancers. High quality of soyshrikhand is applicable for all section of people suffering from lactose intole rance. It is an excellent food for baby/ youth / old/pregnant women. Although what we choose to drink is really a matter of personal prefe rence and our health objectives but looking at the comparison soymilk look healthie $r$ choice.
\end{abstract}

Keywords- Soymilk, soyshrikhand, marke t shrikhand, Fatty acid test.

\section{Introduction}

The soybean (Glycine max) is plant belonging to the family leguminosae and sub family papilionaceae. Several legume based milk and milk products have been developed in attempts to extend the supply of milk like product especially in area where milk is in short supply since legumes are important sources of relatively in expensive protein, introduction of imitation milk product from legumes may contribute to the alleviation of protein malnutrition (Cay gill et al, 1981). Milk is an excellent source of most essential mineral for human it contains mostly calcium, phosphorous $\&$ constitutes the most important source of bio available calcium in our diet (ICAR, 1981).The use of soymilk product in the feed $\&$ food industry has increased steadily the world soybean. Production in correctly 219.8 million matrix ton out of which India produced 9.3 million matrixes. Ton constituting about $4 \%$ of the total world production out of this less than $10 \%$ is directly use for Human consumption (Gandhi 2006). Soybean is an important source of high quality protein for vegetarians $\&$ nonvegetarian alike worldwide (Burke 1996) according to anochili (1984) soymilk as animal milk substitute has been gaining Popularity in the dairy industry and also widely consumed(Bahareh H.et.al 2009).

One of the most important aspects of dairy production is the modeling of the milk yield \& quality (Beev et.al.1991, Kamidi, 2005,
Morant\&Gnanasakthy 1989, Mostert et. al.2003). The quality of milk is better explained by the fat $\&$ protein concentration (Quinn et. al. 2006) .The diets of people in many developing countries comprise mainly starchy roots, ce reals $\&$ few legumes. Unfortunately animal sources of proteins which are used to complement the starchy diets are expensive and out of reach for low -income families (Obatolu et al. 2007).Increasing demand for milk has promoted the need to extend search for its substitute not only in order mammals but also from plant source one of the plant source that attracted focus of people is soya plant is commonly available. It grows well in wide range of soil with optimum growth I $\mathrm{n}$ moist alluvial soil with a good organic contain. Soymilk as animal milk substitute has been gaining popularity in the dairy industry an also widely consumed.

In recent years diffe re nt edible varieties of legumes have been identified that have high nutritional value, $\&$ the refore could to address a number or diet related problems globally. Soybean (Glycine max) is recognized as one of the crops with huge potential the world over. This plant has been exploited for the manufacture of food products such as soybean fertified gori \& tapioca \& ce real-based traditional weaning food (Sanni \& sobamiwa, 1994 Osundahunsi \& Awor, 2003, Kolapo \& sanni 2005).Shrikhand is the indigenous fermented milk product prepared by fermentation of milk using process such as coagulation desiccation 
and fermentation. Shrikhand is extensively used as a sweat dish after meals it is also a as festive sweet in India .sugar is added as additive to the shrikhand to enhance taste and does not have any

Preservative effect .other natural additive like dried fruits are added to the shrikhand to enhance flavor shrikhand is traditionally made at home in we stern Ind ia the name shrikhand is derived from Sanskrit world "shikharini" (shrikhand value added traditional dairy products paper)

This fermentation is bough about by bacteria, therefore yoghurt contain millions of live bacteria which are beneficial to the human digestive system. In flavor we utilize the nutmeg is the seed tree is usually in powder form. Nutmeg is full of minerals, such as manganese, potassium, calcium, \& iron it's not just e nhance the flavor of your food ,but also keep your immune system strong it also excellence for your skin, pain relief, and brain power. Sugar is source for instant energy, low blood pressure and in case of diabetes have fluctuating sugar level. If you are on insulin supplement and do not it food for a long time the blood sugar level in your body goes down. At that point of time your body needs row sugar to revive itself some are used as lower calories foods substitute for sugar describe as artificial sweetness.

\section{Material and Method}

Collection of soybean sample: - collection of soybean from market. Production of soymilk (Cornell's method) soymilk was produce by the process described by Wei.et. al (1978).Illustrated in the chart below:

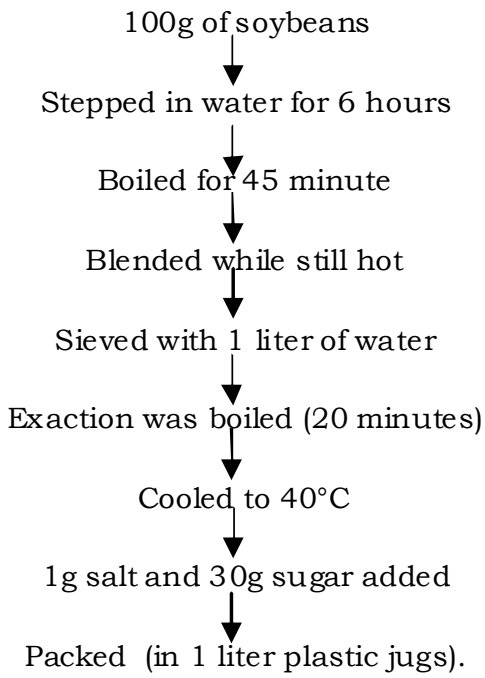

Figure:- Flow diagram illustrating the pre paration of soymilk
Preparation of Soyshrikhand from plant source as a soybean (ICAR 2006).

Soymilk

$\checkmark$

Heating $\left(95^{\circ} \mathrm{C} / 15 \mathrm{~min}\right)$

Cooling to $30^{\circ} \mathrm{C}$

Addition of $2 \%$ curd cultures / lactic acid

bacteria / probiotics as starte r culture<smiles>[3H][3H]</smiles>

Incubation $\left(30^{\circ} \mathrm{C}, 8\right.$ hours, till the acidity reaches $1 \%$ )

Tieing curds in muslin cloth for $8 \mathrm{hrs}$.

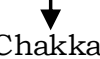

Adding sugar (40\%by weight of chakka) \& cardamom ( $1.6 \%$ by weight of chakka) flavor $\&$

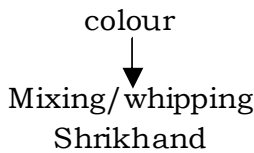

Figure:- flow diagram illustrating the preparation of shrikhand.

\section{Lipid test:}

$10 \mathrm{ml}$ of milk sample was pipette in series of conical flask. 2-3 drop of phenolphthalein indicator was added to it and mixed it Thorley it was titrated against $0.1 \mathrm{~N}$ $\mathrm{KOH}$ up to color changed from colorless to pink.

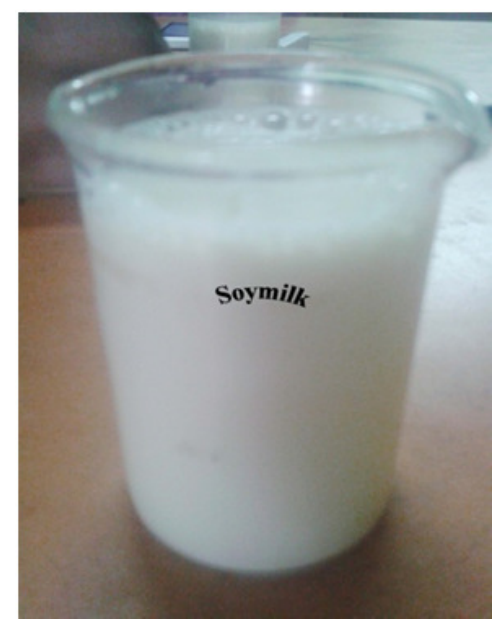

Figure1: - Preparation of soymilk from soya bean seed 


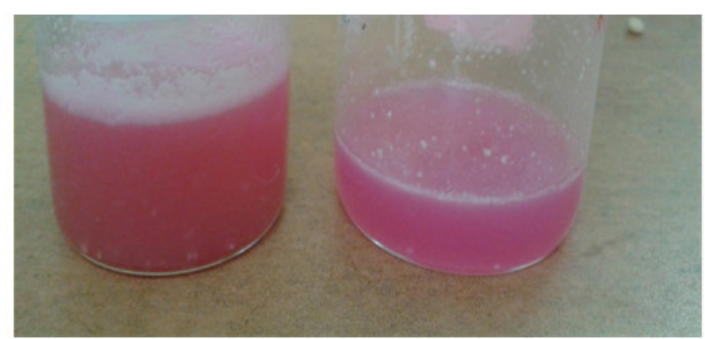

Figure 2 Lipid Test

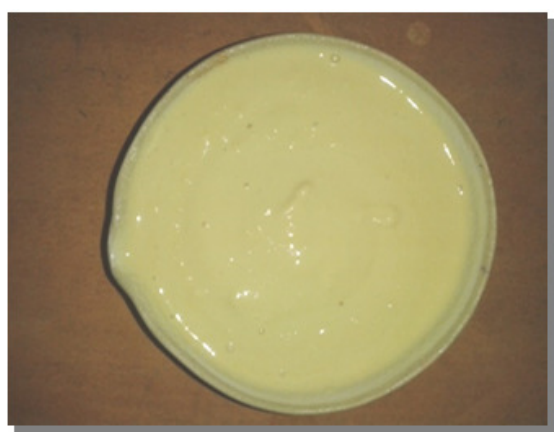

Figure 3:- Soyshrikhand

\section{Result and Discussion}

Soymilk and Soyshrikhand is an expensive remarkable versatile high protein food made from soya bean. Soymilk (plain flavored) is ready to drink and applicable to all section of people suffering from lactose intolerance (infant/ youth/ old pregnant etc). soymilk is white liquid made from seed and they may consist of pure water, soybean, extract, sugar, salt, flavors and permitted food colors (fig.1).Milk contain all the main food classes, fat, carbohydrates, minerals it supplies people with all the necessary amino acid to form protein as well as vitamins all dispersed in water. Soyshrikhand and this milk utilized for dairy product formation Indian fermented milk product utilized $7 \%$ of total milk produced mainly include 3 product dahi, shrikhand and lassi using process such as coagulation ,desiccation and fermentation(fig.2). The fermented milk products constituents a vital component of human diet like a fat.The lipid contain of soymilk shrikhand compare with the buffalo milk shrikhand. The major contrasts in the food proximate content are the values obtained for the fats contents. The concentration of fat obtains in the soymilk shrikhand i.e.7.3 $\mathrm{mg} / \mathrm{ml}$ and buffalo milk shrikhand i.e. $12 \mathrm{mg} / \mathrm{ml}$ (fig.3). It was concluded that the soymilk shrikhand are low in fat as compare to buffalo milk shrikhand.

This significant diffe rence showed buffalo milk to be about higher in fat content than soymilk shrikhand. We specially concentrate only on lipid test because fat/cholesterol is major problem in Indian human being and who does not wish to consume the cow milk / buffalo milk product they can consume soymilk product in high quantity without worry of fat in teak. Another good advantage of soymilk shrikhand is that, it also tends to reduce the fat which come through the consumption of oil and animal fat. The animal milk contains the hormone of animal, they do-contribute to body fat. It has more fiber in it, this very healthy for the digestive system, the omega- 3 and omega- 6 fatty as well as they phyto-oxidant and it also effectively protect your blood vessels and heammorrhage. The flavor nutmeg utilized in powder form and it also provide the minerals, such as manganese, potassium, calcium, \& iron. It's not just enhanced the flavor of your food, but also keeps your immune system strong. it also excellence for your skin, pain relief, and brain power. Sugar is source for instant energy, low blood pressure and in case of diabetes have fluctuating sugar level.

\section{Conclusion}

This study is able to establish the close significant difference in chemical characters the acid value method show the least variation in fat concentration. Soymilk shrikhand has resource of prote in and low in fat that makes it has a no. of unique properties that make it the most preferred milk and product as compared to other animal milk and product (Figure 3).

\section{Reference}

1. Reddy k.k., Pasha Ali, M., Rao B.V. and Jagannadha Rao, T., 1984, studies on production and quality of shrikhand from buffalo milk. India .J Dairy. sci.

2. Cornell's method:-Wei. L.S., A.I. Nelson and M.P. steinberd, 1978. Whole soybean for home and village use. International soy series no.14 international agriculture publication.

3. Baharch H. 2009. Comparison of nutritional and chemical parameters of soymilk and cow milk (world academy of science, engineering and technology).

4. Sensory analysis of banana and blended shrikhand. Rita narayan and Jyothi Lingam. Department of dairy science, madras veterinary college, Chennai, tamilnadu, India.

5. Boghra VR. Mathur ON (2000), physicochemical status of major milk constituents and minerals at various stages of shrikhand preparation J.food, sci. Technology 37.111.115. 
6. Shinde RK (1994) comparative study of fat and SNF losses during the manufacture of shrikhand by different method Msc. Thesis submitted to Dr.B.S.K.K.V. Dapoli.

7. Nigam N. Rashmi S., Upadhayay PK (2009), Incorporation of chakka by papaya pulp in the manufacture of shrikhand. J dairy foods 28(2). 115-118.

8. Khurana H.K. and kanawiia S.K. 2007. Recent trends in development of fermented milks, curr. Nutr. Food, sci. 3:91-108.

9. Patel R.S. and chakra borty B.K. 1985 standardization of shrikhand manufacturing process of lactic fermentation le-lait 65: 5556.

10. Salunke P. Hasmukh A.P. and Thakur P.N .2006. Sensory profile of market shrikhand sold in Maharashtra state Indian j dairy sci. 59: 363-368.

11. Rameshwar S. 2006 characteristics and technology of traditional Indian cultured dairy product. Indian dairy man .58 49-51.

12. Rudrello F. (2004) Heath trends shape innovation for dairy product (online) euromoniter international active; Oct (2005)Shrikhand value added traditional dairy product G. Swapan and Suvarna V. Chavannavar, department of agricultural microbiology, university of Agricultural science, GKVK, Bangalore. Karnataka, India.

13. Obatolu VA, Augustine O, I ken JE 2007 improvement of homemade maize tortilla with soybean. International journal of food science and technology 42:420-426.

14. Beever D.E. A.J. Rook, J.France. M.S. Dhanoa, and M. Gill .1991. A review of empirical and mechanistic models of lactation performance by dairy cow. Livest prod. Sci., 29, 115-130.

15. Kamidi R.E.2005. A parametric measure of lactation persistency in dairy cattle. Live stock production scie nce 96,141-148.

16. Morant, S.V. A. Gnanasakthy. 1989. A new approach to the mathematical formulation of lactation curves. Anim. Prod., 49,151162 .

17. Baharch H. comparison of nutritional and chemical parameters of soymilk and cow milk (world Academy of science engineering and technology 2009).

18. Gandhi A.P. 2006. Soybean -the greater bean. World grain (USA) Feb., issue .p59-62.

19. Fung, S., A.L. lock and P.C. Garnsworthy, 2004.Technical note: A rapid lipid separation method for de te rmination of fatty acid composition of milk .Journal of dairy sci. 87:3785-3788.
20. Creamer, L.K.and A.K. H. macgibbon, 1996. Some recent advance in the basic chemistry of milk protein and lipid. Inte rnational dairy journals $6: 539-568$.

21. Belitz, H.D. and w. Grosch, 1999. Food chemistry in: milk and dairy product. $2^{\text {nd }}$ Ed. Springer - Verlag Berlin Heidelberg New York, PP: 470-472.

22. White ,S.L. , J.A.Bertrand, M. R. wade , S.B. washbarn J.R. green and T.C. Jenkins , 2001.Comparison of fatty acid content of milk from Jersey and Holstein cows consuming pasture or a total mixed ratio . Journal of dairy sci., 84:2295-2301.

23. Palmaquist, D.L., A. Denise, Beaulieu and D.M. Barbano, 1993 .Feed and animal factors .Influencing milk fat composition journal at dairy sci., 76: 1753-1771. 